\title{
Firm-level entrepreneurship and international performance: A simultaneous examination of orientation and action
}

\author{
Mojtaba Hosseini ${ }^{1}$ (D) Hossein Dadfar $^{1}$. \\ Staffan Brege ${ }^{1}$
}

Published online: 14 June 2018

(C) The Author(s) 2018

\begin{abstract}
Relying on the resource-based view and contingency analysis, this study aims to investigate the relationship between firm-level entrepreneurship (FLE) and international performance among Iranian small and medium-sized enterprises (SMEs). The environment is considered as a moderating factor which enables us to discuss the results more precisely. To draw a more holistic picture of entrepreneurship in existing companies, both orientation and action are included in the research model. A survey study of 140 SMEs using a partial least squares structural equation modelling analysis demonstrated a negative effect of entrepreneurial orientation (EO) on international performance, but a positive impact for corporate entrepreneurship (CE). Environmental dynamism (ED) appeared as an insignificant moderator, while environmental hostility (EH) significantly moderated the effect of EO on international performance. The unexpected results of this study, especially in the case of EO, add new insights on the FLE research of smaller companies. When SMEs are performing in a business network, cooperation becomes the priority, and any type of opportunistic behaviour which harms the trust weakens their collective performance.
\end{abstract}

Résumé Reposant sur l'approche fondée sur les ressources et l'analyse des contingences, cette étude vise à investiguer la relation entre l'entrepreneuriat au niveau de l'entreprise et la performance internationale des PME iraniennes. L'environnement est.

Mojtaba Hosseini

mojtaba.hosseini@liu.se

Hossein Dadfar

hossein.dadfar@liu.se

Staffan Brege

staffan.brege@liu.se

1 Department of Industrial and Economic Development (IEI), Industrial Economics (INDEK),

Linkoping University, Linkoping, Sweden 
considéré comme un facteur modérateur qui permet de discuter plus précisément les résultats obtenus. Pour fournir une vue plus holistique de l'entrepreneuriat dans les entreprises existantes, l'orientation ainsi que l'action sont incluses dans le modèle de recherche. Une étude de 140 PME utilisant une analyse PLS-SEM a démontré un effet négatif de l'Orientation Entrepreneuriale (OE) sur la performance internationale, mais un lien positif entre l'entrepreneuriat d'entreprise et la performance internationale. Le dynamisme environnemental est. apparu comme un modérateur insignifiant, tandis que l'hostilité environnementale a notablement modéré l'effet de l'OE sur la performance internationale. Les résultats inattendus de cette étude, en particulier dans le cas d'OE, apportent de nouvelles perspectives sur la recherche l'entrepreneuriat au niveau de l'entreprise des petites entreprises. Lorsque les PME évoluent dans un réseau d'entreprises, la coopération devient la première priorité, et tout type de comportement opportuniste qui nuit à la confiance affaiblit leur performance collective.

Keywords Firm-level entrepreneurship - Entrepreneurial orientation · Corporate entrepreneurship · Environmental dynamism · Environmental hostility · Business network

Mots-clés Entrepreneuriat au niveau de l'entreprise · Orientation Entrepreneuriale · Entrepreneuriat d'entreprise · Dynamisme environnemental · Hostilité environnementale · Réseau d'entreprises

JEL classifications $\mathrm{L} 26 \cdot \mathrm{F} 23 \cdot \mathrm{F} 64$

\section{Summary highlights}

Contribution: This study contributes to the literature by analysing the simultaneous effects of both entrepreneurial orientation and entrepreneurial action on international performance. It is also performed in a developing country, a context that is widely neglected in the current studies of international entrepreneurship.

Research questions/purpose: The purpose of this study is to analyse the effects of entrepreneurial orientation and entrepreneurial action on the international performance of SMEs, when the moderating impact of environment is considered. Therefore, the research has made inquiries about the relationships between EO and CE on international performance of SMEs and whether they lead to the same international performance consequences in different environmental situations.

Theoretical or conceptual framework: On the basis of resource-based view, contingency analysis and reviewing the current literature, we have constructed a theoretical framework which supports and explains the research hypotheses.

Data/information: Data for this study was collected from 140 Iranian food and beverage SMEs. A face-to-face approach was applied to filling out the survey questionnaires. This method is recommended as a useful strategy to reduce the risk of low response rates in developing countries such as Iran. 
Results/findings: We found a negative linkage between entrepreneurial orientation and international performance, but a positive relationship for entrepreneurial action. Considering the cooperative action of Iranian SMEs when they expand into international markets, these findings are plausible. Further analysis reveals that the effect of entrepreneurial orientation on international performance is moderated by environmental hostility.

Limitations: This study is limited to a selected industry in a single country. Therefore, results need to be interpreted and generalized with caution.

Theoretical implications and recommendations: The findings of this study uncover two fundamental theoretical considerations. First, researchers need to choose a proper measurement based on a clear purpose statement when studying FLE. To draw a whole picture, they need to take into account both entrepreneurial orientation and entrepreneurial action. Second, network theory has an excellent potential to complement the entrepreneurship theory of internationalization. Thereby, a synergic effect could be created by incorporating these theories into international business studies.

Practical implications and recommendations: This study recommends that SMEs look at their international entrepreneurial strategies from a network perspective. They need to align their entrepreneurial orientation with the common objectives of their business network. In this way, they can develop a synergic strategy that paves the way to international markets.

Suggestions for future research: Future studies can apply a more comprehensive theoretical framework in which entrepreneurship and network theories are incorporated to explain the internationalization of SMEs. Also, similar studies can be carried out in different contexts to increase the generalizability of the results.

\section{Introduction}

As a new stream of research, firm-level entrepreneurship (FLE) has gradually become an integral part of the entrepreneurship and strategic management literature. The number of studies on the subject has increased over the past decade in such a way that several meta-studies have been performed to summarize the collective results (e.g. Rauch et al. 2009; Saeed et al. 2014). The current literature supports a positive relationship between FLE and corporate performance (Rauch et al. 2009; Wales et al. 2011) or FLE and international performance (Dimitratos et al. 2004; Knight 2000; Liu et al. 2011; Zhou et al. 2009), which provides a solid foundation, encouraging more research.

The idea of studying entrepreneurship at established companies was first presented in Peterson and Berger's (1971) study of the music industry. They described entrepreneurship as a specific type of strategy, which helps companies to cope with turbulent markets. However, until Covin and Slevin's (1989) seminal paper on entrepreneurial posture, the field did not receive much attention. Covin and Slevin (1989) reinvestigated and empirically validated Miller's (1983) concept of entrepreneurial 
posture, and paved the way for subsequent studies by introducing a reliable conceptualization and operationalization of the phenomenon. Another stream of the research that fundamentally influenced the field was Burgelman's (1983) study of corporate venturing and Pinchot's (1985) work on intrapreneurship. While Covin and Slevin had mainly focused on entrepreneurial orientation, these researchers took a different perspective and brought the actual entrepreneurial activities into consideration. The lack of consensus on what entrepreneurship means and how it should be measured was evident from the outset; different studies proposed diverse explanations of entrepreneurship and the way it could be measured. Generally, three separate views have been developed around the topic: first, entrepreneurship as specific characteristics of a group of people or organizations (characteristic view); second, entrepreneurship as desired outcomes for companies or national economies (outcome view); and third, entrepreneurship as the process of doing things in given industrial or organizational contexts (process view). Following this classification, Covin and Slevin's study of entrepreneurial posture can be seen as the product of the characteristic and process view, while Burgelman's corporate venturing has been evolved from the outcome perspective of entrepreneurship.

The research on FLE initially originated from large companies, but later studies indicated that smaller companies are also able to benefit from recruiting entrepreneurial strategies, and even more so than their larger counterparts (Antoncic and Hisrich 2004). The most apparent benefit of FLE, nurtured and supported by a large body of conceptual and empirical research, is its favourable effect on corporate performance. Casting a quick glance at FLE studies, it would appear that the majority of the literature has focused on domestic performance and that international performance has been ignored to a large extent. In reference to the globalization movement, the SMEs' barriers to entering international markets, and the firmly established connection of entrepreneurship and internationalization as an independent field of study (commonly known as international entrepreneurship), the scant amount of research on FLE and international performance is quite extraordinary.

The first definition of international entrepreneurship had explicitly relied on FLE as an essential part of the field (See McDougall and Oviatt 2000, p. 903). This definition was later altered to better emphasize opportunity exploration and exploitation; still, understanding how international entrepreneurs grasp opportunities to create new ventures and perform entrepreneurial activities across borders is a major topic in international entrepreneurship. In response to this gap and to compensate for the lack of entrepreneurship research in developing countries, this study attempts to explain the effect of FLE on the international performance of Iranian food and beverage SMEs. Thus far, the majority of FLE studies have been performed in the USA and other developed countries, and little understanding of the phenomenon exists in developing areas such as the Middle East, Latin America, Sub-Saharan Africa, Eastern Europe, and South Asia (Wales et al. 2011). The Iranian food and beverage industry provides a unique context for such research. In Iran, around 99.8\% of all registered businesses are SMEs which in turn are responsible for $54.6 \%$ of the total employment in the country (UNIDO 2003). The second most productive industry is food and beverage with around 7370 active companies, of which $94 \%$ are SMEs that need immediate attention (Hosseininia and Ramezani 2016), specifically with regard to their internationalization (Hosseini 2016). 


\section{Firm-level entrepreneurship: Clarifying the concept}

A principal challenge that emerged from the very beginning is the lack of agreement on defining and measuring the FLE construct. This confusion led researchers to apply different labels to name and define the concept such as entrepreneurship (Miller 1983), entrepreneurial posture (Covin and Slevin 1991), entrepreneurial orientation (Lumpkin and Dess 1996; Stambaugh et al. 2017), corporate entrepreneurship (Burgelman 1983; Zahra 1991), and intrapreneurship (Antoncic 2007; Menzel et al. 2007; Pinchot 1985). Employing different labels and conceptualizations, which actually indicate different concepts or the different dimensions of the same concept, results in persistent confusion and leads to contradictory findings among empirical studies. In the absence of an allinclusive conceptualization, researchers are advised to rely on a consecutive approach in which the literature is reviewed to identify, separate, and categorize the dimensions, and their individual and collective outcomes are then studied to make inferences about the higher-order construct of FLE.

Among all the concepts in the FLE studies, entrepreneurial orientation (EO), corporate entrepreneurship (CE), intrapreneurship, and entrepreneurial management (EM) have drawn the most attention. Covin and Miles (1999) categorized these constructs into three different groups: (1) employees as entrepreneurs (e.g. intrapreneurship), (2) entrepreneurship as an entire philosophy or orientation (e.g. EO and EM), and (3) entrepreneurship as new entries (e.g. CE). This classification provides a proper footing to separate various dimensions or recognize different types of FLE. Intrapreneurship deals with the personal characteristics of intrapreneurs (Antoncic et al. 2004), employees who present and implement innovative ideas in their organizations. It limits the focus to entrepreneurial employees and admits an individual level of analysis. FLE, in essence, is an entire organizational philosophy or an overall strategy that is not limited to a group of select people. It originates from all sections, flows through the whole system, and grows in a harmonic coordination of organizational functions. Therefore, intrapreneurship that is regarded as a concept helping researchers to understand entrepreneurial employees has been excluded from our research model, in which FLE is considered as a whole-firm phenomenon admitting a firm level of analysis.

The second theme extends the entrepreneurial activities to the whole organization and defines FLE as an orientation or a type of management. Defining FLE as an orientation or posture proved immensely popular in the literature. EO has become the most approved measurement of FLE in that a number of meta-analyses have been done to summarize the collective results of the related studies (e.g. Rauch et al. 2009; Saeed et al. 2014). In contrast, entrepreneurship as a style of management has not attracted much attention (Gartner and Baker 2010). The original study by Stevenson and Jarillo (1990), who conceptualized entrepreneurial management, has been mainly cited for its opportunitybased definition of entrepreneurship rather than its proposed measurement of FLE (Kuhn et al. 2010). To be in line with the current literature and to avoid the complexity of analysis, this paper relies on EO to capture the tendency of a company toward entrepreneurship.

Although EO is a well-known and a widely-approved construct, conceptualizing a broad phenomenon such as FLE based on orientation alone does not draw a holistic picture because it only covers the attitudinal aspect, while "entrepreneurship has attitudinal and behavioral components" (Morris 1998, p. 17). In addition, entrepreneurship is usually defined as the process of exploration and exploitation (Shane and Venkataraman 2000). 
This means entrepreneurship happens only when an entrepreneurial opportunity is discovered, and a unique package of resources is brought together to exploit that. Discovering an opportunity without realizing it or exploiting an existing opportunity could not be seen as true entrepreneurship. EO has mainly focused on the exploration, values, and organizational tendency to search and screen business opportunities, and does not count the realized opportunities. In other words, showing a high level of EO does not guarantee entrepreneurial success because the shortage of resources in an organization may lower the probability of actual entrepreneurial outputs.

The last theme is entrepreneurship as new entries. This theme of entrepreneurship accepts an output-based view and focuses on the behavioural component of FLE. CE is a popular construct of this category. It relies on entrepreneurial actions and enumerates the number of new ventures, innovations, and the level of self-renewal as the indications of entrepreneurial success (Simsek et al. 2007; Zahra 1991). As it is obvious, this construct also counts on one dimension of entrepreneurship: the behavioural component. Unlike EO, which primarily focuses on opportunity exploration, CE captures opportunity exploitation by taking the entrepreneurial outputs into consideration. It values the visible outputs of entrepreneurship such as new products or services, new ventures, and self-renewal, and nearly ignores the orientation.

Some researchers add to the confusion by using EO, CE, and even intrapreneurship interchangeably (Antoncic 2007; Menzel et al. 2007). To explicate the concept and elucidate the current jargon of the field, this study separates FLE, intrapreneurship, EO, and $\mathrm{CE}$ as distinctive constructs. EO and CE are respectively defined as an entrepreneurial tendency and entrepreneurial actions of companies which jointly display the degree of FLE. Furthermore, intrapreneurship differs from other constructs in terms of the level of analysis. While EO and CE measure entrepreneurship at the firm level, intrapreneurship adopts an individual level of analysis dealing with individual intrapreneurs in a typical organization.

As discussed earlier, EO shows a strategic orientation (Covin and Slevin 1989), a tendency to act innovatively and proactively, and to take calculated risks when facing entrepreneurial opportunities (Miller 1983). Researchers have used different sets of dimensions to measure this notion of entrepreneurship. The original conceptualization proposed by Miller (1983) and Covin and Slevin (1989) listed the three dimensions of innovativeness, proactiveness, and risk-taking. Later, Lumpkin and Dess (1996) criticized this conceptualization and added two extra dimensions: aggressiveness and autonomy. There are many researchers who employed different versions of EO, including more or fewer than three dimensions. A meta-analysis study performed by Rauch et al. (2009) confirmed that applying a slightly modified version with more or fewer than three dimensions does not affect the overall validity of the construct. Thereby, this paper adheres to the three-dimensional construct of EO because it is widely accepted (Rauch et al. 2009; Wales et al. 2011) and supported by a large body of research.

Innovativeness refers to the tendency to support creativity and experimentation that could be put into operation in different areas of business (Knight 2000; Rauch et al. 2009). Proactiveness shows an organizational posture which is characterized by opportunity-seeking, a forward-looking perspective that acts upon forthcoming needs and wants (Rauch et al. 2009; Wiklund and Shepherd 2005). Finally, risk-taking reflects the tendency of a company to allocate resources to projects in which the probability of return and failure is high (Knight 2000). To sum up, all the dimensions of 
innovativeness, proactiveness, and risk-taking denote a type of tendency or orientation which plainly diverges from actual entrepreneurial behaviour or outcomes. This issue is clearly highlighted in Hansen et al. (2011) explanation of EO dimensions, which says: "Innovative behaviors are borne from a tendency to enter into experimentation, support new ideas, and depart from established practices; proactive behaviors reflect a propensity to act aggressively towards rival firms in the pursuit of favorable business opportunities; and risk-taking behaviors result from a willingness to make investments in projects that have uncertain outcomes or unusually high profits and losses." (p. 62).

$\mathrm{CE}$ measures the actual engagement of a firm in entrepreneurship activities, reflects the entrepreneurial behaviour, and thus differs from EO, which depicts an orientation or tendency (Simsek et al. 2007). CE captures both formal and informal entrepreneurial activities (Zahra 1996) and is frequently defined by the three dimensions of innovation, venturing, and strategic renewal ${ }^{1}$ (Antoncic and Hisrich 2004). Innovation departs from innovativeness, a dimension of EO that reflects the capacity or tendency of an organization toward innovation (Garcia and Calantone 2002). Innovation is considered to be the real combination of resources (Nahapiet and Ghoshal 1998), discoveries which result in actual production and boost the economic value of a firm (Garcia and Calantone 2002), or a continued commitment to introduce new products, services, and technologies (Zahra 1996). Corporate venturing, a kind of action that may occur throughout a company (Zahra 1993), encompasses all the activities of creating new risky businesses within or by an established company. Strategic renewal involves redefining a firm's relationships with markets and competitors, transforming the fundamental values that direct the strategic moves (Antoncic 2007), and absorbing new knowledge that modifies core competencies and changes the strategic position (Memili et al. 2011). It includes all activities causing significant changes in the business model, corporate strategies, and organizational structures.

According to the above discussion, EO and CE are two distinct measurements of FLE, which may have different performance consequences, especially for SMEs, which do not have access to the necessary resources for converting their orientation into action. A quick review of the literature demonstrates that the majority of the empirical research has applied only one construct (EO or CE), and a few studies focused on studying both constructs simultaneously. In reference to Knight (1997), who stated that EO is more suitable for determining the orientation while CE aims at measuring the entrepreneurial activities, and Lumpkin and Dess (1996), who distinguish between EO as the processes, practices, and decision-making indicating the tendency of managers to act entrepreneurially and $\mathrm{CE}$ as new entries which explain what entrepreneurship really consists of, focusing on $\mathrm{EO}$ or $\mathrm{CE}$ alone could be misleading. It may result in a onedimensional explanation that only covers one aspect of entrepreneurship. This challenge is even worse in the international entrepreneurship literature, where almost all studies only investigate the effect of $\mathrm{EO}$ or $\mathrm{CE}$ on international performance, and their simultaneous effects are extensively disregarded. Therefore, this research is intended to answer these questions: What are the effects of $\mathrm{EO}$ and $\mathrm{CE}$ on the international performance of SMEs? Do they produce the same international performance consequences in different environmental situations?

\footnotetext{
${ }^{1}$ There are CE studies which used fewer dimensions (e.g. Hornsby et al. 2009), although compared to EO studies, they are smaller in number.
} 


\section{Theoretical framework and hypotheses development}

In a systematic review of the resource-based view (RBV) in international studies, Peng (2001) came to the conclusion that SMEs are not able to compete with large multinational companies in terms of tangible resources; instead, they should rely on "intangible resourcefulness, that is, the ability of doing more with less" (p. 818). From the RBV perspective, FLE can be considered to be a major intangible resource of SMEs, which is rare, valuable, inimitable, and non-substitutable, and thus can help them to achieve a competitive advantage in international markets. A company which possesses a higher level of FLE can discover international opportunities faster and realize them in a more optimized way than others. Defining FLE as a rare, valuable, inimitable, and nonsubstitutable resource that assists companies to compete in international markets successfully (Zahra and George 2002) and helps them to create value in early internationalization by increasing their competitive advantage (Zahra 2005) is a well-known application of the RBV in international entrepreneurship studies. Until now, the empirical (e.g. Covin and Slevin 1989; Lumpkin and Dess 2001; Wiklund and Shepherd 2005) and conceptual (e.g. Covin and Slevin 1991; Lumpkin and Dess 1996; Zahra 2005) studies of international entrepreneurship corroborate well with this theoretical framework.

However, there are a few studies that found only a partial (e.g. Dimitratos et al. 2004; Jin et al. 2017; Zhang et al. 2012; Zhou et al. 2009) or no significant connection (e.g. Jantunen et al. 2005) between EO and international performance; the majority of EO empirical studies (e.g. Glavas et al. 2017; Knight 2000; Knight and Cavusgil 2004; Liu et al. 2011; Thanos et al. 2017) confirm a positive relationship. For instance, in their study of international success, Contractor and Kundu (2004) found an entrepreneurial orientation with a peculiar emphasis on glocalization (simultaneous handling of both local and international market demands) as a way to attain international success. The current literature underpins the RBV explanation of FLE as a featured resource that could help companies to achieve superior international performance.

Hypothesis 1: SMEs' entrepreneurial orientation positively influences their subsequent international performance.

Unfortunately, the number of empirical studies on $\mathrm{CE}$ and international performance is not adequate to infer a collective conclusion. The few current empirical studies on the whole construct (e.g. Yiu et al. 2007) or venturing as a recognized dimension of CE (e.g. Zahra et al. 1997) indicate a significant positive connection. In accordance with these few studies, the RBV explanation of CE as a rare, valuable, inimitable, and nonsubstitutable resource that supports companies to achieve superior performance, and empirical studies of corporate performance which confirm a positive effect of corporate entrepreneurship, make it plausible to conclude the next hypothesis.

Hypothesis 2: SMEs' corporate entrepreneurship positively influences their subsequent international performance. Although EO and CE are discussed as two dimensions of the same construct, this does not mean that they should be discussed at the same level. In fact, EO could be viewed as an orientation or tendency which may lead to successful CE activities (Lumpkin and Dess 1996). The amount of owned or controllable resources is a necessary medium in translating EO into superior performance (Lyon 
et al. 2000). A recent empirical study performed by Stambaugh et al. (2017) supported a type of EO-CE connection among a sample of 156 community banks headquartered in the Southwestern United States. Using banks' risk-weighted asset ratio, which captures the actual risk-taking behaviour of the banks, Stambaugh et al. (2017) confirmed a significant positive relationship between an orientation to take risks and the level of actual risk-taking. In another study performed in Austria, Switzerland, and Germany, Klammer et al. (2016) demonstrated EO as an antecedent of strategic renewal. These recent studies are in line with others, which highly recommend entrepreneurial orientation as a posture that determines entrepreneurial activities (Rauch et al. 2009; Wiklund and Shepherd 2003).

Hypothesis 3: SMEs' entrepreneurial orientation positively influences their subsequent corporate entrepreneurship.

As discussed before, a disagreement exists in the current empirical research on the relationship between EO and international performance. Implementing different types of indicators to measure performance (Hughes and Morgan 2007) or the contingency nature of the EO-performance connection (Lumpkin and Dess 1996; Rauch et al. 2009) are considered the potential causes of this inconsistency. Several studies have been performed to determine if employing different measurements of performance might result in different conclusions in the business (e.g. Dess and Robinson 1984; Wall et al. 2004) or entrepreneurship research (Rauch et al. 2009). All the studies revealed a significant correlation between perceptual and archival measures of performance and did not find a considerable deviation in their links with other organizational variables. Rauch et al. (2009) in particular found no difference between EO studies which used perceptual financial, perceptual non-financial, and archival measures of performance. Consequently, measuring performance using different types of indicators could not be regarded as enough of a serious challenge to cause the existing disagreement.

In their conceptual model, Lumpkin and Dess (1996) discussed environmental factors and organizational characteristics as intermediate factors that may modify the intensity or direction of the EO-performance connection. Environmental factors are increasingly considered to be moderating variables that could influence the way EO is configured to result in superior performance (Wiklund and Shepherd 2005). EO studies place their attention on the outcome rather than the process; therefore, the context could play an essential role (Dess et al. 2011). Recognizing the importance of environmental factors in the EO-performance connection recalls the contingency analysis of organizational functions. Companies need to fit their strategies with the environment if they want to act successfully (Venkatraman and Prescott 1990). From this perspective, the fit is considered to be a way that strategy and environment pair together to improve performance. Contingency analysis is frequently employed in empirical research on EO (Rauch et al. 2009; Wales et al. 2011), and is in line with the contingency approach of internationalization developed by Cavusgil and Zou (1994) and Yeoh and Jeong (1995). This approach supposes FLE as a way to enhance international performance when the environment is aligned with entrepreneurial strategies. Supporting this perspective, there are a number of studies which confirmed that the extent to which FLE relates to international performance is dependent on the presence of other factors such as cultural intelligence (Șahin and Gürbüz 2017), absorption capacity (Hernandez- 
Perlines 2018), stronger channel management capability (Boso et al. 2017), international networking, and opportunity recognition (Bianchi et al. 2017).

Although the environment could be conceptualized and measured using different indicators, environmental hostility $(\mathrm{EH})$ and environmental dynamism (ED) received more attention in the FLE literature (Rauch et al. 2009). ED refers to a favourable environment in which business opportunities are continuously created, and companies are encouraged to be at the edge of technological change (Zahra 1993). EH, in contrast, shows an unfavourable environment in which companies' missions are threatened, and their survival is in danger (Zahra 1991, 1993). When a business environment becomes hostile or dynamic, companies can change the market where they compete or change their strategy of competition (Zahra et al. 1997). Leaving the current market for a new one (new entry) or choosing a proactive strategy to compete in a hostile or dynamic environment could both be seen as different forms of entrepreneurship (Lumpkin and Dess 1996, 2001). As a result, FLE including EO and CE helps companies to manage and compete in hostile or dynamic environments successfully. This inference is supported by the current empirical research (Rauch et al. 2009) and is in consonance with Yeoh and Jeong's (1995) model of contingency analysis. Yeoh and Jeong's model of contingency analysis describes entrepreneurial and conservative firms as unique organizations with specific characteristics, each of which works better under proper environmental conditions. When the business environment is benign and stable, conservative companies outreach entrepreneurial firms, but entrepreneurial firms perform better in dynamic and hostile environments.

Hypothesis 4: ED moderates the relationship between EO and international performance in a way that the effect of EO on international performance will be stronger when the level of ED is high.

Hypothesis 5: ED moderates the relationship between $C E$ and international performance in a way that the effect of CE on international performance will be stronger when the level of ED is high.

Hypothesis 6: EH moderates the relationship between EO and international performance in a way that the effect of EO on international performance will be stronger when the level of EH is high.

Hypothesis 7: EH moderates the relationship between CE and international performance in a way that the effect of $C E$ on international performance will be stronger when the level of EH is high.

\section{Methodology}

\section{Sample Selection and Data Sources}

This research has been performed in Iran, a currently neglected country in the international entrepreneurship literature. In fact, the majority of FLE studies in general, and international entrepreneurship in particular, are carried out in developed countries such as the USA (Dess et al. 2011) and European countries, and there is limited understanding of the 
phenomenon in undeveloped or developing areas such as Latin America, Sub-Saharan Africa, Eastern Europe, the Middle East, and Southern Asia (Wales et al. 2011). To specify the research and somehow control the confounding effects of company size and industry environment, respondents in our study were limited to food and beverage SMEs, companies with fewer than 250 employees (Commission 2003), which manufacture, package, and distribute food and beverage products.

To reduce the probability of a low response rate and avoid the challenges and difficulties associated with mail and email surveys in developing countries such as Iran, a face-to-face approach was employed to fill out the survey questionnaires. This method of data collection is common in countries where collecting primary data using mail or email is challenging and difficult (Zhou et al. 2009), and is recommended as a useful strategy to reduce the risk of having a low response rate (Bryman 2012). There are several professional databases to collect a primary sample of Iranian companies, such as the TPO and KOMPASS7 business-to-business directories. These databases may work better for drawing a sample of larger companies, but they do not deliver reliable data for SMEs. Thus, this study relies more on official archives such as the Institute of Standards and Industrial Research of Iran (ISIRI), Bushehr Fisheries Organization, Iran Small Industries, and the Industrial Park Organization (ISIPO) to identify the target companies. A group of professional interviewers were instructed to carry out the survey. Cooperating with local interviewers provides better access and more valid and reliable information (Zhou et al. 2007). Companies were contacted by phone or visited in person after their union or institutional meetings. The purpose, benefits, and procedure of the study were briefly presented, and they were assured of confidentiality.

Of the 324 companies contacted or visited, 216 agreed to participate in the research. An interview meeting was individually scheduled with the CEO of each company. Interviews were structured in three sections. They started by presenting a brief introduction to the study; continued by discussing the general conditions of the company, industry, and the environment; and finished by filling out the survey questionnaire (Appendix). In total, 198 usable questionnaires were collected. Fifty-eight companies were removed from further analysis because they did not meet the condition of being international; thus, the effective response rate is about $43.21 \%$, higher than that of similar studies in the field (e.g. Knight and Cavusgil 2004). However, the non-response rate of $56.79 \%$ provides good protection against non-response bias. The extrapolation method of non-response bias on demographic characteristics of early and late respondents was also used to double-check whether any difference exists between respondents and non-respondents. Comparing earlier and later respondents based on age $(t=1.549$, $P>.05)$ and size $(t=1.147, P>.05)$ revealed no significant difference, indicating that non-response bias is not a major concern. Because all the questionnaires were filled out by the companies' CEOs, the common method bias could also be a potential problem. Harman's one-factor approach was used to check if the common method bias is a serious problem. An explanatory factor analysis of principal component analysis summarized all indicators in eight main factors with eigenvalues greater than 1.0, in which the first factor only accounted for $19.45 \%$ of the variance. Furthermore, a confirmatory factor analysis on a unidimensional factor of all items revealed a low fit $(\mathrm{CMIN} / \mathrm{DF}=4.674, \mathrm{CFI}=0.326, \mathrm{RMSEA}=0.160$, and $\mathrm{SRMR}=0.2090)$. Thus, the common method bias is not a challenging issue here. 


\section{Variables and measures}

Structural equation modelling (SEM) forms a solid basis on which to test and elaborate existing theories (Diamantopoulos 2011), and has thus become popular in entrepreneurship and small business studies. An essential part of SEM analysis, which is especially important for theory testing, is measurement model validation. In the absence of a rigorous measurement validation, a study cannot test what it truly wants to test. A measurement model validation in SEM analysis is usually carried out in two separate but related steps. The first step encompasses defining and assigning the proper measurement model and the second deals with the reliability and validity. It is the measurement model assigned to a variable which directs the proper techniques for its reliability and validity.

\section{Step one: Measurement model assignment}

In their review of entrepreneurship and small business studies, Wang et al. (2013) showed that $53.9 \%$ of all reviewed studies had misspecified their measurement model. This ignorance has directed researchers to suppose that all measurements should be treated equally, regardless of their measurement model. Ignoring the measurement model assignment, especially in SEM analysis, could cause bias and reduce confidence in the results. Therefore, the relationship between measurements and their indicators should be closely examined, even if those measures have been previously used and validated by other researchers (Petter et al. 2007). Two common types of measurement models are discussed in research methodology; reflective and formative. For reflective measurement models, the direction of causality is from the construct to the indicators, errors are considered at the indicator level, and all indicators are supposed to covary and depict the same antecedents and outcomes as the overall construct. For formative measurement models, indicators cause and form the construct, disturbance is taken into attention at the construct level, indicators may have different antecedents and outcomes, ${ }^{2}$ and there is no reason to expect them to covariate with each other (see MacKenzie et al. (2005), Jarvis et al. (2003), Petter et al. (2007), and Diamantopoulos (2011) for a detailed description).

Sometimes, formative measurements show patterns similar to reflective ones, which misleads researchers who only look at empirical data to check the measurement models of their constructs (Petter et al. 2007); checking the theoretical relationship between indicators and constructs, therefore, is the first priority of measurement model validation (Jarvis et al. 2003). We incorporated both theoretical discussion and empirical evidence to determine the measurement model of the constructs in this study. A guideline suggested by Jarvis et al. (2003) was applied to frame the discussion. This guideline proposed four simple rules to check on measurement models: Rule 1, Direction of causality (from construct to indicators for reflective and vice versa for formative measures); Rule 2, Interchangeability of indicators (interchangeable for reflective, non-interchangeable for formative measures); Rule 3, Are indicators expected to covariate with each other? (Yes for reflective, no for formative measures); and

\footnotetext{
${ }^{2}$ Having different outcomes as a specific characteristic of the formative measurement model has been severely questioned (see Diamantopoulos (2011) for more details).
} 
Rule 4, Are indicators expected to have similar antecedents? (Yes for reflective, no for formative measures).

$\mathrm{EO}, \mathrm{ED}, \mathrm{EH}$, and familiarity, which pay attention to the perception or tendency of companies, were operationalized as reflective measures, while $\mathrm{CE}$, a construct that captures the actual entrepreneurial outcomes, was formulated as a formative measure. A quick look at the nature and development process of these constructs illuminates how they should be connected to their indicators. In the case of environmental factors, indicators replicate similar contents that reflect the perception of CEOs regarding the business environment (Rule 2). It is reasonable to expect all the indicators to change when the environment changes (Rule 1); thus, they have the same antecedents (Rule 4), and removing one item causes little harm to the whole construct (Rule 3).

Discussing the measurement models of EO and CE is more complicated because they are multidimensional constructs. In the beginning, Miller (1983) developed the construct of entrepreneurial posture by reviewing and summarizing three common themes of entrepreneurship. Each of the themes, which later became known as the dimensions of EO, had been previously characterized and applied as independent measures of the whole construct. Miller thereby defined and treated EO as a reflective measure of entrepreneurial posture in terms of innovativeness, proactiveness, and risktaking. Changes in the whole construct of EO caused by internal or external factors mean changes in all dimensions (Rule 1); therefore, indicators share a significant amount of variance (Rule 2). If the business environment becomes less dynamic, or a shared vision is not created, the tendencies to take risks, be innovative, or act proactively will all decrease meaning dimensions covariate with each other (Rule 3). As is clearly stated in the literature, all these tendencies are defined and measured as specific attributes of CEOs or management boards, and therefore they have a lot in common (Rule 4). In an extreme example, all the dimensions will change if the CEO or management board change. Using data from 93 countries during the period 1980-2008, Mthanti and Ojah (2017) drew the same conclusion, demonstrating EO as a reflective second-order construct with three indicators which covary.

In contrast to EO, which is explained as some kind of tendency, $\mathrm{CE}$ is commonly defined as the different types of entrepreneurial activities such as innovation, venturing, and strategic renewal. CE dimensions can be considered as distinctive steps of a process. An entrepreneurial company with access to the necessary resources is able to introduce an innovation. This innovation may need a new organizational structure inside or outside the company to be appropriately managed, and this new organizational structure could force or stimulate the company to reconfigure strategies, managerial structure, and markets. The process-wise activities do not share similar antecedents (Rule 4), are not interchangeable (Rule 2), may not covariate (Rule 3), and all combine to form a whole process (Rule 1). CE from this perspective is an overall process of all three components and is incomplete if any of them is removed. This inference is in line with the standard practices of business methodology, in which latent perceptual variables are usually formulated as reflective (Petter et al. 2007) and activity-based variables are defined as formative measurement models. When the perception is in focus, the latent construct is usually considered as the predictor of its indicators, but in the case of output measurements, indicators are often caused by the latent variable (see the example of intoxication by Diamantopoulos (2011), p. 336). 
To measure EO and $\mathrm{CE}$ - the independent variables of the research - and $\mathrm{EH}$ and ED - the moderator variables - previously validated measurements were implemented. The original EO construct proposed by Miller (1983)/Covin and Slevin (1989) was used to measure the entrepreneurial orientation; to do so for the actual activities of entrepreneurship, Zahra's (1991) measurement of corporate entrepreneurship was applied. The environmental hostility and environmental dynamism were measured using the well-known constructs of Miller and Friesen (1982). One indicator of $\mathrm{CE}^{3}$ was removed because of its apparent overlap with international performance. All these variables were measured consistently, using a 7-point Likert scale. The Likert scale conveys interval properties, which provides a basis for applying more sophisticated techniques of data analysis, and has been commonly implemented in similar studies (Robertson and Chetty 2000).

There are other factors besides FLE that could affect international performance. To reach a more precise conclusion, we needed to control their effects. The most influential variables of this kind identified and discussed in the current empirical studies are firm size (Rauch et al. 2009; Wiklund and Shepherd 2005; Zhang et al. 2012; Javalgi and Todd, 2011; Ripolles Meliá et al. 2007), international experience of CEOs (Lan and Wu 2010; Jantunen et al. 2005; Zhang et al. 2012; Dimitratos et al. 2004) and familiarity with foreign markets (Johanson and Vahlne 1977; Dimitratos et al. 2004). Firm size is operationalized as the number of employees in the current year of operation (Dunning 1988; Pan et al. 1999). International experience is the number of years that a firm's CEO had spent studying or working abroad (Contractor and Kundu 2004). Familiarity is a more complicated variable, defined as the amount of similarity between the host and international markets in terms of mentality and language, socio-cultural norms, and socio-cultural values (Johanson and Vahlne 1977; Root 1994). Relying on the existing literature, size, and previous international experience were defined as single-indicator variables. Familiarity, which was operationalized as a reflective three-indicator latent variable (Dimitratos et al. 2004), was measured using a 7-point Likert scale. To remove the confounding effects of firm size, international experience, and familiarity, they were added to the PLS statistical model as control variables. Additionally, limiting the scope of the study to a single industry in a selected country protected the results against the unwanted influence of industry structure and international culture.

There are researchers who applied a single criterion such as foreign sales ratio or the number of international markets to measure international performance, yet such a simple criterion fails to capture the complexity of the phenomenon (Sullivan 1994). A two-dimensional operationalization of international scale and scope, which draws a more holistic picture, is a common indicator of international performance (Ripolles et al. 2007; Sullivan 1994; Zahra et al. 1997; Zhang et al. 2012). In a review study of international performance, Walters and Samiee (1990) concluded that about $68 \%$ of all the papers used the international scale, and around $13 \%$ used the international scope to measure international performance. While the scope shows the number of foreign markets where a company operates, the international scale is defined as the percentage of total sales from international markets (Ripolles et al. 2007; Zahra et al. 1997). Table 1 summarizes the variables, their operationalization in this research and their measurement model assignment. The last column of the table shows the proper

\footnotetext{
${ }_{3}^{3}$ We have expanded our international operations significantly.
} 


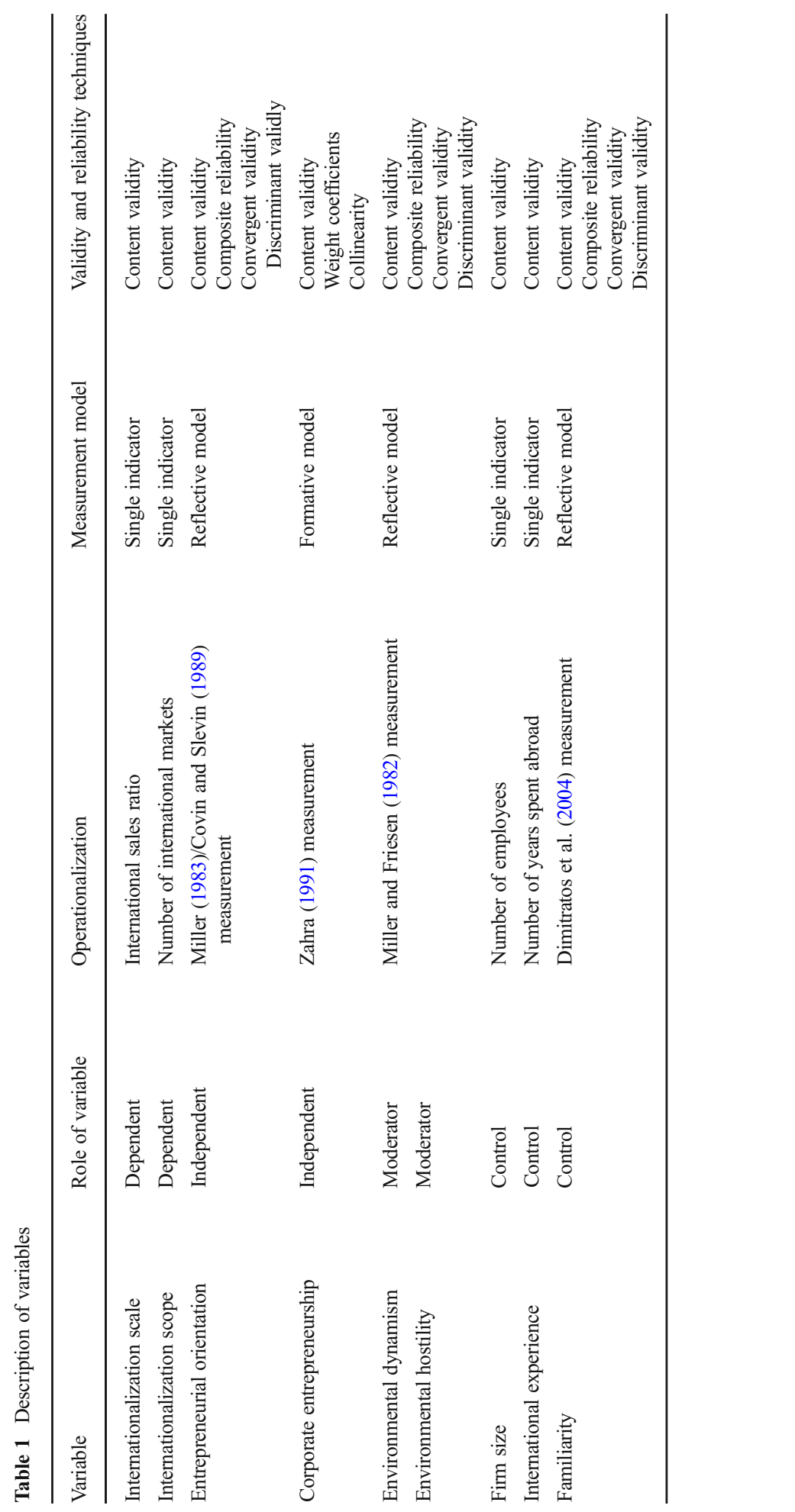


techniques for assessing the reliability and validity of the variables based on their specific measurement models.

\section{Step two: Validity and reliability assessment}

Assessing the validity and reliability of the constructs is a necessary step that needs to be taken before performing the PLS-SEM analyses. We followed guidelines issued by Hair et al. (2014) and Becker et al. (2012) to prepare and evaluate the measurements, and executed the PLS-SEM analyses using the SmartPLS software (Version 3) (Ringle et al. 2015). Internal consistency is a necessity for the reflective measurement model, but this is not the case for the formative measurement model, in which the indicators' covariance is not a requisite. Thus, reflective constructs are evaluated based on their internal consistency, specific measures such as composite reliability, convergent validity, and discriminant validity. As a common rule of thumb, a composite reliability greater than .7 is desirable. However, a value greater than .6 can be regarded as acceptable. To assess convergent validity in PLS-SEM, researchers need to look at the outer factor loadings and the average variance extracted (AVE). Indicators with outer factor loading less than .4 or indicators with factor loading between .4 and .7 , where deleting them improved the composite reliability or with AVE above the suggested thresholds, should be removed. This is the necessary but not sufficient condition for convergent validity. To meet the convergent validity, a construct must also display an AVE value greater than .5. The discriminant validity could be established by checking on cross-loadings, comparing the square root of the AVE value with the latent variable correlations (Fornell and Larcker's (1981) criterion), and using a newer version of the Heterotrait-Monotrait ratio of correlations (HTMT).

In the case of formative constructs, the content validity, significance of weight coefficients, and presence of collinearity have been considered as necessary conditions to meet the validity and reliability. Collinearity, which is regarded as a problem for formative measures, is desired among reflective measurement models (Jarvis et al. 2003). Removing an indicator from a reflective measure is a commonly accepted practice, while deleting an indicator could alter the meaning of a formative measure, and only happens rarely and with scrutiny (Diamantopoulos 2011). Consequently, checking for content validity throughout, which ensures all the indicators of a formative construct are captured, is a mandatory practice (Petter et al. 2007).

All the variables have been used previously, and content has been validated by the current literature on entrepreneurship and international business. To be confident about the Persian translation of the questionnaire, a back-translation was performed by an entrepreneurship lecturer at the University of Teheran. This process revealed no difference in the meaning of the questions.

The internal consistency of all reflective measures-EO, EH, ED, individual dimensions of EO (innovativeness, proactiveness, and risk-taking), different dimensions of $\mathrm{CE}$ (innovation, venturing, and self-renewal), and familiarity - was checked in terms of composite reliability, convergent validity, and discriminant validity. Firstly, indicators with loading factors smaller than .4 were removed (EH3 (.211), EH2 (.324), EOP1 (.156), and CEV6 (.406)). Still, the convergent validity of EH was not met (AVE =

.481 ), and therefore, another indicator was dropped (EH5 (.542)). By putting these indicators aside, all the constructs met the conditions of convergent validity (see the 
Table 2 Measurement model analysis

\begin{tabular}{|c|c|c|c|c|c|}
\hline Construct (SO) & Measurement model & SL & SW & CR & AVE \\
\hline Entrepreneurial orientation & Reflective & & & .907 & .548 \\
\hline innovativeness & Reflective & $.839 * * *$ & & .851 & .657 \\
\hline EOI1 & & $0.829 * * *$ & & & \\
\hline EOI2 & & $0.819 * * *$ & & & \\
\hline EOI3 & & $0.783 * * *$ & & & \\
\hline Proactiveness & Reflective & $.915^{* * *}$ & & .930 & .869 \\
\hline EOP2 & & $0.932 * * *$ & & & \\
\hline EOP3 & & $0.932 * * *$ & & & \\
\hline Risk-taking & Reflective & $.917 * * *$ & & .944 & .850 \\
\hline EOR1 & & $0.930 * * *$ & & & \\
\hline EOR2 & & $0.934 * * *$ & & & \\
\hline EOR3 & & $0.902 * * *$ & & & \\
\hline Corporate entrepreneurship & Formative & & & & \\
\hline innovation & Reflective & & $.392 * * *$ & .867 & .570 \\
\hline CEI1 & & $0.842 * * *$ & & & \\
\hline CEI2 & & $0.804 * * *$ & & & \\
\hline CEI3 & & $0.765^{* * *}$ & & & \\
\hline CEI4 & & $0.804^{* * *}$ & & & \\
\hline Venturing & Reflective & & $.437 * * *$ & .900 & .692 \\
\hline CEV1 & & $0.844 * * *$ & & & \\
\hline CEV3 & & $0.867 * * *$ & & & \\
\hline CEV4 & & $0.76^{* * *}$ & & & \\
\hline CEV5 & & $0.852 * * *$ & & & \\
\hline Strategic renewal & Reflective & & $.321 * * *$ & .897 & .636 \\
\hline CER3 & & $0.851 * * *$ & & & \\
\hline CER4 & & $0.86^{* * *}$ & & & \\
\hline CER5 & & $0.775^{* * *}$ & & & \\
\hline Environmental dynamism & Reflective & & & .890 & .618 \\
\hline ED1 & & $0.81 * * *$ & & & \\
\hline ED2 & & $0.772 * * *$ & & & \\
\hline ED3 & & $0.771 * * *$ & & & \\
\hline ED4 & & $0.785^{* * *}$ & & & \\
\hline ED5 & & $0.791 * * *$ & & & \\
\hline Environmental hostility & Reflective & & & .774 & .538 \\
\hline EH1 & & $0.751 * * *$ & & & \\
\hline EH4 & & $0.595 * * *$ & & & \\
\hline EH6 & & $0.833^{* * *}$ & & & \\
\hline Familiarity & Reflective & & & .949 & .860 \\
\hline F1 & & $0.913 * * *$ & & & \\
\hline $\mathrm{F} 2$ & & $0.928^{* * *}$ & & & \\
\hline F3 & & $0.941 * * *$ & & & \\
\hline
\end{tabular}

$S L$ standard loading (applicable for reflective measurements), $S W$ standard weight (applicable for formative measurements), $C R$ composite reliability, $A V E$ average variance extracted. $* P<.05$, $* * P<.01$, and $* * * P<.001$ (2-tailed) 
standard loadings (SLs) and AVE values in Table 2). None of the indicators displayed a cross-loading greater than its own factor, which confirmed the necessary condition of discriminant validity. Also, the square root of all AVE values was larger than the correlation between the latent variables (Table 3), ensuring discriminant validity based on Fornell and Larcker's approach. The HTMT criterion, however, led to slightly different results. Self-renewal and innovation did not meet the discriminant validity in terms of this criterion (HTMT values smaller than .9). Thereby, CESR1 and CESR2 from self-renewal and CEI5 from innovation were removed. The composite reliability of all the constructs was also greater than .7 (Table 2), which confirmed the reliability of the variables mentioned above.

As discussed before, $\mathrm{CE}$ has been defined as a formative construct; thus, the standard weights of manifested variables (individual dimensions of innovation, venturing, and self-renewal) and their possible collinearity were studied. Fortunately, all the standard weights were significant, and the variance inflation factor (VIF) values of all the manifested variables were far below 5 (Table 2).

\section{Results and discussion}

There are two types of hierarchical latent variable models in this research: the reflective-reflective second-order construct of EO and the reflective-formative second-order construct of CE. Evaluating and determining the appropriate approach to estimate the parameters in these types of variable models is a necessary initial step in PLS-SEM studies. The typical way to calculate reflective-reflective models is the repeated indicator approach. This becomes more complicated, however, in the case of reflective-formative models. Researchers have used a two-step approach to estimate reflective-formative models instead of the repeated indicator. A simulation study performed by Becker et al. (2012) revealed the repeated indicator as a better approach to estimate reflective-formative models, which produces less bias, a more precise estimate, and a more stable higher-order construct score. Therefore, all the hierarchical latent variable models in this study were estimated using the repeated indicator approach.

The research model also contains interaction effects, thus a proper way needed to be chosen to calculate the interaction variables. Four different ways of calculation are presented in PLS-SEM analysis: product indicator calculation, two-stage calculation, hybrid calculation, and orthogonalizing calculation. Based on the results of a simulation study, Henseler and Chin (2010) confirmed the two-stage calculation as being statistically more powerful; thus, it could be regarded as a proper way to calculate interaction effects in a confirmatory study.

In the absence of universal fit indices in the PLS-SEM analysis to assess the model quality, researchers are advised to report the predictive measures, such as the coefficients of determination ( $R$-square values) and the predictive relevance of endogenous variables ( $Q$-square values) (Hair et al. 2014). $R$-square values indicated that about $49.4 \%$ variance of international scale and approximately $46.6 \%$ variance of international scope were explained by the model, revealing a moderate predictive capability. $Q$ values of international scale (.357), international scope (.352), and CE (.483) were all greater than zero, which confirms the predictive relevance of endogenous paths. All in 


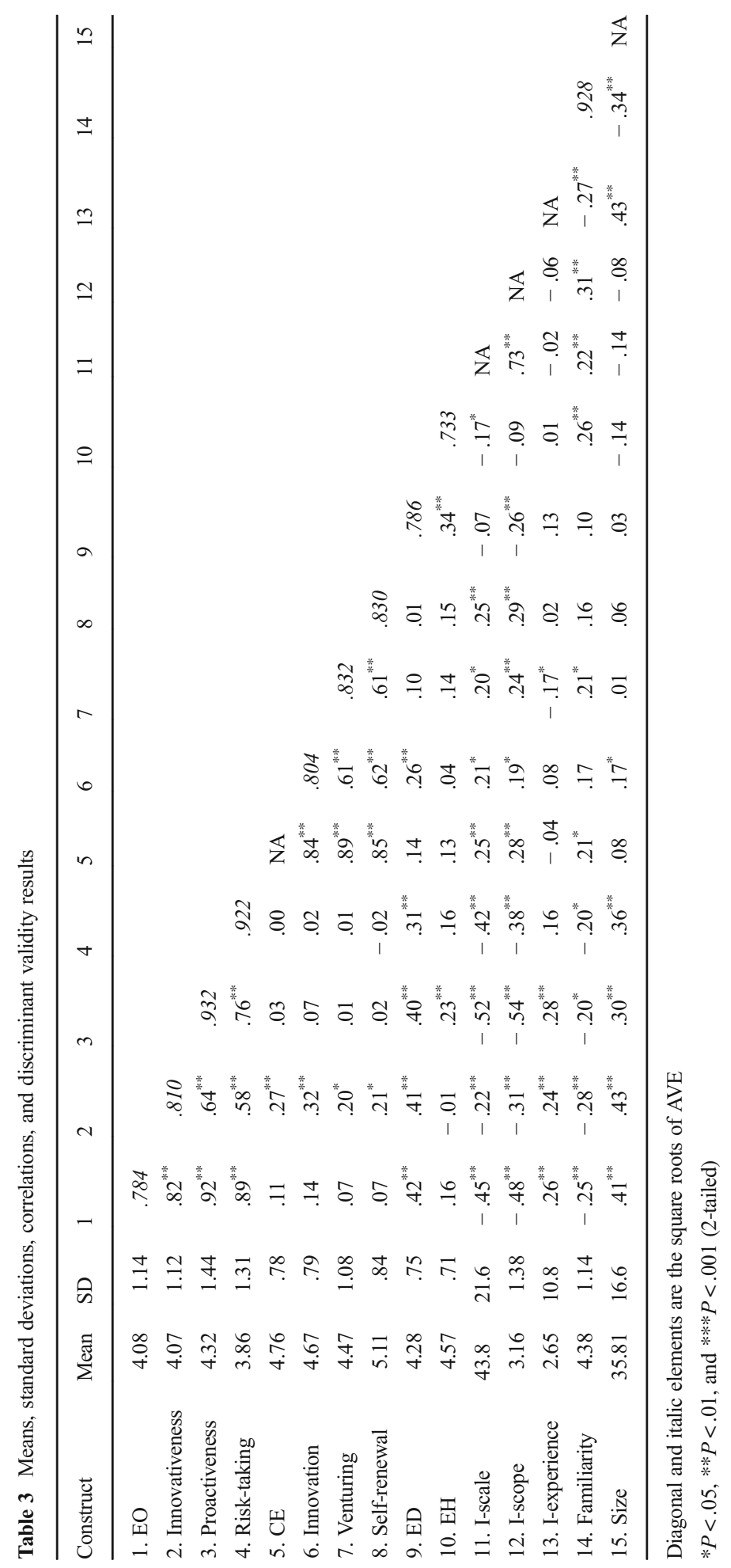


all, the $R$-square and $Q$-square values assured a moderate to high predictive capacity of the research model.

Table 4 shows the final results, and Fig. 1 summarizes all the measurements and path analyses in an easy-to-read schematic model. Familiarity with foreign markets, the size of the company, and the international experience of the CEO revealed no effects on the international scale. However, the effects of familiarity and size were significant on international scope; their effect sizes ( $F$-square values in Table 4$)$ were small, demonstrating they are not statistically meaningful ( $F$-square values lower than .10 , close to $.02)$. EO showed a significant relationship with both dimensions of international scale $(\beta=.657, P<.001)$ and international scope $(\beta=.517, \mathrm{P}<.001)$, but a non-significant effect on $\mathrm{CE}(\beta=.001, P=.421)$. In contrast to what it was expected, the EO relationship with both dimensions of international performance was negative. Considering the $F$-square, these negative values were both statistically meaningful ( $F$-square values larger than .10). These results do not support $\mathrm{H} 1$ and $\mathrm{H} 3$, supposing a positive relationship between EO and international performance, as well as between EO and CE.

To explain why EO reveals an adverse effect on international performance, we need to expand our perspective beyond the firms and look at their business networks. The companies studied relied more on cooperation and creating a synergic network to identify and realize international opportunities rather than competition. In some cases, they formed a collective network informally led by a more prominent company that coordinated all the business activities. The informal leader could be a solo private

Table 4 Significant testing results of the structural model path coefficients

\begin{tabular}{lllllll}
\hline & Coefficients & $t$ values & $P$ values & Confidence interval $95 \%$ & $F$-square \\
\hline Familiarity - > I-scale & .050 & .613 & .540 & -.672 & -.319 & .004 \\
Familiarity - > I-scope & .224 & 2.586 & .010 & .887 & .942 & .066 \\
IE - > I-scale & .084 & 1.096 & .274 & .888 & .939 & .010 \\
IE - > I-scope & .077 & .976 & .330 & -.109 & .205 & .008 \\
Size - > I-scale & .127 & 1.355 & .176 & .048 & .390 & .017 \\
Size - > I-scope & .186 & 2.058 & .040 & -.070 & .238 & .034 \\
EO - > I-scale & -.657 & 7.405 & .000 & -.807 & -.468 & .455 \\
EO - > I-scope & -.517 & 5.625 & .000 & .799 & .883 & .266 \\
CE - > I-scale & .294 & 2.830 & .005 & .103 & .512 & .127 \\
CE - > I-scope & .280 & 2.654 & .008 & .040 & .452 & .109 \\
EO - > CE & -.001 & .805 & .421 & -.005 & .000 & .024 \\
ED*EO - > I-scale & -.141 & 1.421 & .156 & -.307 & .076 & .024 \\
ED*EO - > I-scope & -.072 & .766 & .444 & -.266 & .096 & .006 \\
ED*CE - > I-scale & -.160 & 1.530 & .127 & -.348 & .065 & .032 \\
ED*CE - > I-scope & .026 & .237 & .813 & -.163 & .269 & .001 \\
EH*EO - > I-scale & .321 & 2.795 & .005 & -.025 & .474 & .180 \\
EH*EO - > I-scope & .218 & 1.899 & .058 & -.096 & .376 & .079 \\
EH*CE - > I-scale & -.198 & 1.576 & .116 & -.382 & .107 & .054 \\
EH*CE - > I-scope & -.237 & 1.845 & .066 & -.477 & .047 & .074 \\
\hline
\end{tabular}

Italic elements indicate the significant paths 


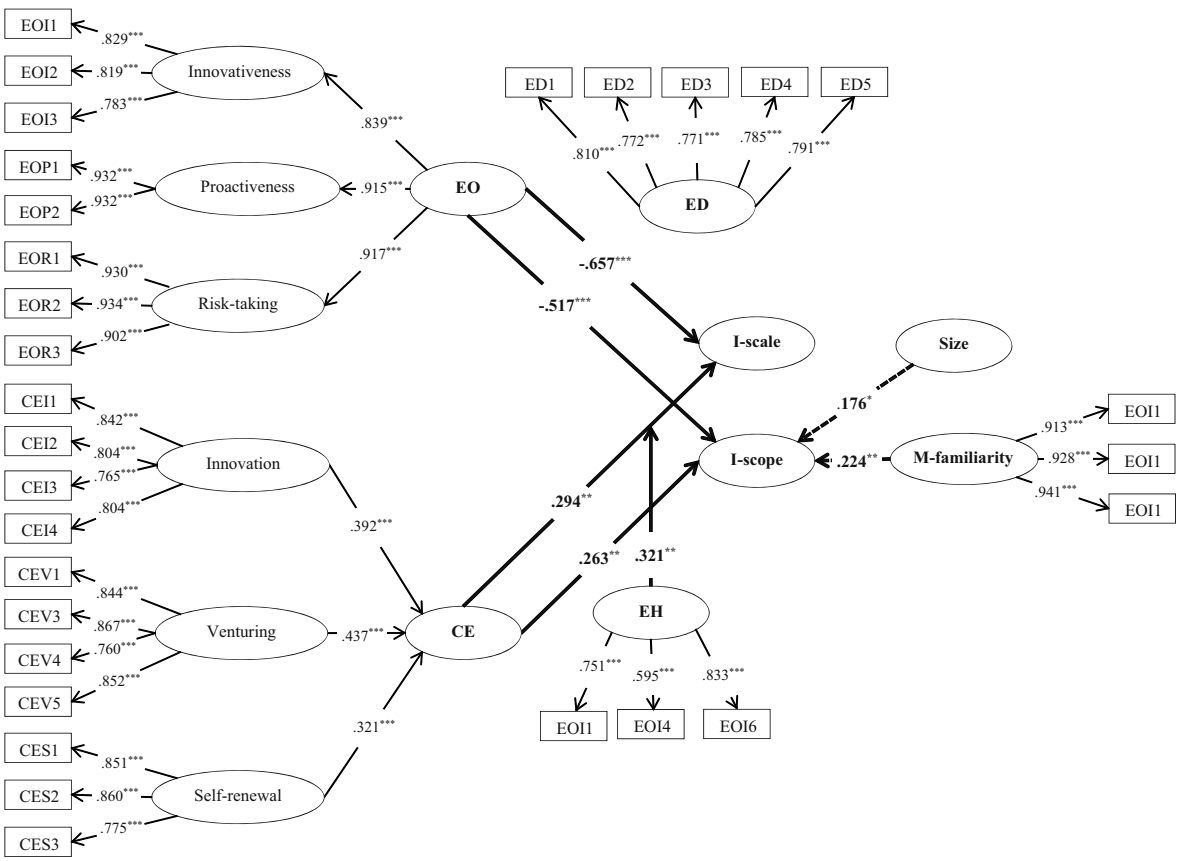

Fig. 1 The schematic model of factor and path analysis. ${ }^{*} P<.05,{ }^{*} P<.01$, and ${ }^{*} P<.001$ (2-tailed)

supplier, a prominent international dealer, or even an effective public institution. Showing a high level of proactiveness or risk-taking in such a network is interpreted as opportunistic behaviour, and thus harms the interrelated cooperation and widens the trust gap among the members. Decreasing the trust in a cooperative network leads to diminishing synergic effect and weakens the international performance of all the actors. From an empirical standpoint, this explanation is corroborated well by the results of a recent study, performed by Song et al. (2017) among South Korean start-ups. They found a complex process of networking, EO, and knowledge acquisition to achieve effective opportunity recognition, in which knowledge acquisition could result in a better opportunity recognition when the EO is low. They concluded that the autonomy and the preference to leverage their own resources prevent those with high EO from acting efficiently in business networks. From a theoretical standpoint, this is also supported by Burt's (2001) theory of network autonomy, in which a whole business network is divided into internal and external sub-networks. Burt described an optimized entrepreneurial network as a structure, in which the external part full of structural holes is supported by a dense internal sub-network. This theory was later explained as a particular form of entrepreneurship by Aldrich and Zimmer (1986). They matched Burt's theory of network autonomy with the entrepreneurship process of opportunity exploration and exploitation. Based on Aldrich and Zimmer's notion, the structural holes in an external sub-network provide a solid foundation to identify, and having an intensified internal network characterized by a high level of trust helps to exploit opportunities. Any opportunistic behaviour that harms the collective trust weakens the group efficiency in opportunity exploitation and decreases the overall performance of all the members. 
$\mathrm{CE}$, on the other hand, indicated a significant positive relationship with both dimensions of international scale $(\beta=.294, P<.001)$ and international scope $(\beta=.280, P<.001)$. The $\mathrm{F}$-square values greater than .10 confirmed a statistically meaningful connection and support $\mathrm{H} 2$, which assumes a positive relationship between $\mathrm{CE}$ and international performance. The cooperative nature of international activities among the investigated companies could be regarded again as a plausible explanation for why $\mathrm{CE}$ influences international performance in a different direction than EO. In contrast to EO, CE is defined as an output-based construct measuring the actual entrepreneurial actions of companies. In a business network, which is established to improve international performance, all the members cooperate to develop innovations, create supporting ventures and modify organizational structures in coping with new environments. These types of activities are undertaken collectively, directed by an informal network leader, and, in contrast to EO, increase the mutual trust. In other words, while the EO dimensions are defined at the firm level, represent the tendency of an individual company, and could translate into opportunistic behaviour that ultimately reduces the collective performance, the CE activities emanate from cooperation, increase the network harmony, and lead to a better aggregate performance. This is because the output-based actions are coordinated, transferred, and executed better in an Iranian business network, in which members occupy different positions and there is a high level of opportunistic behaviour.

Except for the significant moderating effect of environmental hostility on the connection between EO and international scale $(\beta=.321, P<.001)$, other moderating effects were all insignificant. A closer look at the $P$ values, however, revealed the moderating effect of environmental hostility on the linkages of EOinternational scope $(\beta=.218, P<.10)$ and CE-international scope $(\beta=-.237$, $P<.10)$ as partially significant. Consequently, among all the moderating hypotheses, only H6 which assumes a moderating effect for EH on EOinternational performance is partially supported. To get a better picture of how environmental hostility moderates the link between EO and international performance, a simple slope analysis was conducted. As Fig. 2 shows, in a
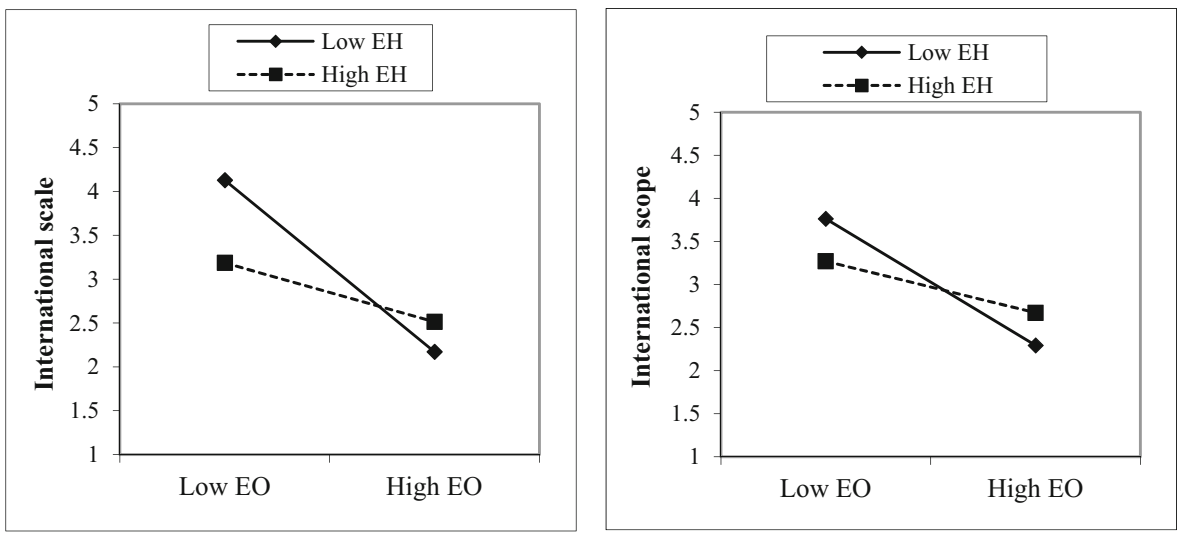

Fig. 2 International performance predicted by EO at low and high levels of EH 
more hostile environment (dotted line), the negative effect of EO on international performance is weaker. This happens because entrepreneurial orientation fits better with the hostile environment (Rauch et al. 2009), in which SMEs can receive better rewards for their individual entrepreneurial strategies.

If we view CE dimensions as collectively manageable activities which are welcomed in a business network and EO as some type of tendency that is not allowed, then this conclusion suggests interesting facts about the collective international performance of SMEs in a hostile environment. Increasing the hostility in a business environment may not affect-or may show a small negative effect on-the aggregate international performance of SMEs, but it significantly influences their individual international performance. When a business environment becomes more hostile, the negative effect of tendency to act on one's own-by showing more innovative and proactive behaviour and making more risky decisions - on international performance will decrease. This can happen because, in the hostile environments, SMEs receive better rewards for their individual activities, which somehow compensates for what they lose due to being excluded from their business networks.

\section{Conclusions}

A significant proportion of empirical studies in the entrepreneurship literature employs EO, or less frequently CE, to measure FLE. Examining these constructs uncovers a surprising fact, one which is ignored to a large extent. Each construct of EO or CE alone regulates one aspect of FLE, and neither of them is able to draw a holistic picture of the whole phenomenon. EO shows the orientation of a typical firm or, more accurately, the tendency of a company's $\mathrm{CEO}$ to act innovatively, react proactively, and take calculated risks. CE, on the other hand, criticizes this tendency as a real proxy of FLE and defines the actual entrepreneurial activities of innovation, venturing, and self-renewal as an ultimate measure. While the first applies an input-based view relying on the entrepreneurial tendency, the second counts on the entrepreneurial outputs. EO is an attribute-based construct that supports explorative styles and $\mathrm{CE}$ is a behaviour-based measure that enables companies to exploit opportunities. Considering entrepreneurship as a process of exploring and exploiting business opportunities encompassing two distinct dimensions of entrepreneurial attributes and entrepreneurial behaviour, researchers need to study both constructs simultaneously. In fact, it is plausible to account for $\mathrm{EO}$ and $\mathrm{CE}$ as the different dimensions of FLE, which are not interchangeable but complementary.

We included both EO and CE and studied the simultaneous effects of both on the international performance of Iranian SMEs. Contrary to what we expected, EO and $\mathrm{CE}$ influenced international performance in different ways; while EO negatively affected international performance, CE displayed a significant positive relationship. The collective nature of the SME's international activities in Iran could be regarded as a probable explanation for why EO and $\mathrm{CE}$ affect international performance differently. EO is commonly defined as a kind of tendency, a specific attribute assigned to the companies' CEOs, which 
helps them to be more efficient when acting individually. However, when companies are performing in an entrepreneurial network in which trust serves as an essential factor, EO may encourage them to show more opportunistic behaviour that weakens the collective performance. In contrast, $\mathrm{CE}$ accounts for innovation, venturing, and self-renewal, actual entrepreneurial activities that could potentially be regarded as common objectives. CE activities, when defined as the group objectives, increase the harmony among all the actors in a business network, augment the teamwork outputs, and improve the collective performance.

A contingency analysis of FLE and international performance using the environmental factors of hostility and dynamism resulted in no significant moderating effect for environmental dynamism. Environmental hostility only moderated the impact of EO on international performance and did not influence the relationship between $\mathrm{CE}$ and international performance. Again, the cooperative international activities of the investigated companies are referenced to describe these conclusions. Environmental dynamism refers to the opportunities and resources that the environment can provide for SMEs. Businesses which rely on cooperation are acting as a whole body to find and capture opportunities. They share their knowledge and resources and are less dependent on environmental munificence. In simpler terms, the necessary expertise and resources to grasp the opportunities come from the cooperation, not from the institutions; thus, they are less dependent on the environmental dynamism. However, the story is different with environmental hostility. In a more hostile environment, where survival is threatened by environmental pressure, companies receive better rewards for their individual EO. This somehow compensates for the collective benefit that they could obtain through being a member of a business network.

Although this study has limitations, it makes significant contributions to the research on entrepreneurship and business network. First, it shows that FLE is a complex phenomenon which needs to be studied through a combination of both orientation and action. Relying only on one dimension may result in misleading conclusions. Second, this paper yields evidence that FLE is highly dependent on the social context, and therefore the existing theories in the literature based mainly on the experience from developed countries cannot fully explain the phenomenon in developing economies. Third, this research is one of the few, if not the first, to investigate both entrepreneurial orientation and action and connect them to the business network. This mechanism of FLE, in which the orientation needs to be aligned with the common objectives of business networks to produce positive performance consequences, could frame future research on the subject. 


\section{Appendix 1: Questionnaire}

Date of establishment:

Number of current employees:

Date of your first foreign sale:

Number of current foreign markets:

Ratio of foreign sales to total sales:

Number of years spent working or studying abroad:

Over the past 5 years...

\begin{tabular}{|c|c|}
\hline & Strongly disagree \\
\hline $\begin{array}{l}\text { We have pioneered the development of breakthrough } \\
\text { innovation in our industry }\end{array}$ & 1234567 \\
\hline $\begin{array}{l}\text { Our organization is among the first to implement new } \\
\text { processes }\end{array}$ & 1234567 \\
\hline $\begin{array}{l}\text { We are usually the first to recognize and exploit new } \\
\text { markets in our industry }\end{array}$ & 1234567 \\
\hline $\begin{array}{l}\text { Our organization is a leader in the area of product and } \\
\text { process innovations }\end{array}$ & 1234567 \\
\hline $\begin{array}{l}\text { We have introduced a large number of new products and } \\
\text { services to the market }\end{array}$ & 1234567 \\
\hline Our organization has entered many new industries & 12345667 \\
\hline $\begin{array}{l}\text { We have expanded our international operations } \\
\text { significantly }\end{array}$ & $\begin{array}{lllllll}1 & 2 & 3 & 4 & 6 & 7\end{array}$ \\
\hline $\begin{array}{l}\text { We have acquired many companies in very different } \\
\text { industries }\end{array}$ & 1234567 \\
\hline $\begin{array}{l}\text { Our organization has created various new lines of } \\
\text { products and services }\end{array}$ & 12334567 \\
\hline $\begin{array}{l}\text { Our organization has established or sponsored various } \\
\text { new ventures }\end{array}$ & 12334567 \\
\hline $\begin{array}{l}\text { We have focused on improving the performance of our } \\
\text { current business rather than entering new industries }\end{array}$ & 1234567 \\
\hline We have divested several unprofitable units & 1234567 \\
\hline Our organization has changed its strategy for each unit & 12334567 \\
\hline $\begin{array}{l}\text { We have initiated several programmes to improve the } \\
\text { productivity of our units }\end{array}$ & 1234567 \\
\hline $\begin{array}{l}\text { We have reorganized operations to ensure increased } \\
\text { coordination and communication among units }\end{array}$ & 12334567 \\
\hline $\begin{array}{l}\text { Our organization has renewed the portfolio of activities } \\
\text { within units }\end{array}$ & 1234567 \\
\hline
\end{tabular}


In general, the senior managers in my firm have...
A strong emphasis on the marketing of
1234567
A strong emphasis on $R \& D$,
tried and tested products or services
technological leadership and innovations

How many new lines of products or services has your firm marketed in the past 5 years?

No new lines of products or services

$\begin{array}{lllllll}1 & 2 & 3 & 4 & 5 & 6 & 7\end{array}$

Very many new lines of products or services

Changes in product or service lines

$1234567 \quad$ Changes in product or service lines have

have been mostly of a minor nature usually been quite dramatic

In dealing with its competitors, my firm...

Typically responds to actions which

$\begin{array}{lllllll}1 & 2 & 3 & 4 & 5 & 6 & 7\end{array}$

competitors initiate

$\begin{array}{llllllll}1 & 2 & 3 & 4 & 5 & 6 & 7 & \text { Is very often the first business to }\end{array}$

Is very seldom the first business to

introduce new products/services, introduce new products/services,

administrative techniques, operating

technologies, etc.

Typically seeks to avoid competitive

122344567 administrative techniques, operating technologies, etc.

clashes, preferring a 'live-and-let-live'

Typically adopts a very competitive, posture

'undo-the-competitors' posture

In general, the senior managers in my firm have...
A strong proclivity for low-risk
$\begin{array}{lllllll}1 & 2 & 3 & 4 & 5 & 6 & 7\end{array}$
A strong proclivity for high-risk projects projects (with normal and certain rates (with chances of very high returns) of return)

In general, the senior managers in my firm believe that...

Owing to the nature of the

122345567 environment, it is best to explore it gradually via timid, incremental behaviour
Owing to the nature of the environment, bold, wide-ranging acts are necessary to achieve the firm's objectives

When confronted with decision-making situations involving uncertainty, my firm...

Typically adopts a cautious, 'wait-andsee' posture in order to minimize the probability of making costly decisions
$1234567 \quad$ Typically adopts a bold, aggressive posture in order to maximize the probability of exploiting potential opportunities 
Please answer the following questions for the industry that accounts for the largest part of your sales (in other words, your principal industry). How rapid or intense is each of the following in your main industry?

\begin{tabular}{|c|c|c|}
\hline $\begin{array}{l}\text { Our firm rarely has to change its } \\
\text { marketing practices to keep up with } \\
\text { the market and competitors }\end{array}$ & 1234567 & $\begin{array}{l}\text { Our firm has to change its marketing } \\
\text { practices extremely frequently (e.g. semi- } \\
\text { annually) }\end{array}$ \\
\hline $\begin{array}{l}\text { The rate at which products/services } \\
\text { become obsolete in the industry is } \\
\text { very slow (e.g. basic metals like } \\
\text { copper) }\end{array}$ & 1234567 & $\begin{array}{l}\text { The rate of obsolescence is very high (as } \\
\text { in some fashion goods and semi- } \\
\text { conductors) }\end{array}$ \\
\hline $\begin{array}{l}\text { Actions of competitors are quite easy } \\
\text { to predict (as in some primary } \\
\text { industries) }\end{array}$ & 1234567 & Actions of competitors are unpredictable \\
\hline $\begin{array}{l}\text { Demand and consumer tastes are fairly } \\
\text { easy to forecast (e.g. for milk } \\
\text { companies) }\end{array}$ & 1234567 & $\begin{array}{l}\text { Demand and tastes are almost } \\
\text { unpredictable (e.g. high fashion goods) }\end{array}$ \\
\hline $\begin{array}{l}\text { The production/service technology is } \\
\text { not subject to very much change and is } \\
\text { well established (e.g. in steel } \\
\text { production) }\end{array}$ & 1234567 & $\begin{array}{l}\text { The modes of production/service change } \\
\text { often and in a major way (e.g. advanced } \\
\text { electronic components) }\end{array}$ \\
\hline $\begin{array}{l}\text { The environment causes a great deal of } \\
\text { threat to the survival of our firm }\end{array}$ & 1234567 & There is very little threat to survival \\
\hline \multicolumn{3}{|c|}{ How severe are the following challenges: } \\
\hline & This is not a great threat & This is a very substantial threat \\
\hline Tough price competition & & 1234567 \\
\hline $\begin{array}{l}\text { Competition in product quality or } \\
\text { novelty }\end{array}$ & & 1234567 \\
\hline Dwindling markets for products & & 1234567 \\
\hline Scarce supply of labour/materials & & 1234567 \\
\hline Government interference & & 1234567 \\
\hline
\end{tabular}

The domestic country is very similar to the foreign country with respect to:

\begin{tabular}{lllllllll} 
& \multicolumn{1}{c}{ Very untrue } & & \multicolumn{1}{c}{ Very true } \\
\cline { 2 - 4 } Mentality and language & 1 & 2 & 3 & 4 & 5 & 6 & 7 \\
Socio-cultural norms & 12 & 3 & 4 & 5 & 67
\end{tabular}


Open Access This article is distributed under the terms of the Creative Commons Attribution 4.0 International License (http://creativecommons.org/licenses/by/4.0/), which permits unrestricted use, distribution, and reproduction in any medium, provided you give appropriate credit to the original author(s) and the source, provide a link to the Creative Commons license, and indicate if changes were made.

\section{References}

Aldrich HE, Zimmer C (1986) Entrepreneurship through social networks. In: Sexton DL, Smilor RW (eds) The art and science of entrepreneurship. Ballinger, Cambridge, pp 3-23

Antoncic B (2007) Intrapreneurship: a comparative structural equation modeling study. Ind Manag Data Syst 107(3-4):309-325

Antoncic B, Hisrich RD (2004) Corporate entrepreneurship contingencies and organizational wealth creation. J Manag Dev 23(6):518-550

Antoncic B, Cardon MS, Hisrich RD (2004) Internationalizing corporate entrepreneurship: the impact on global HR management. In Katz AJ, Shepherd DA (eds) Advances in entrepreneurship, firm emergence and growth, vol. 7. Emerald Group Publishing Limited, pp. 173-197

Becker JM, Klein K, Wetzels M (2012) Hierarchical latent variable models in PLS-SEM: guidelines for using reflective-formative type models. Long Range Plan 45(5-6):359-394

Bianchi C, Glavas C, Mathews S (2017) SME international performance in Latin America. Journal of Small Business and Enterprise Development 24(1):176-195

Boso N, Oghazi P, Hultman M (2017) International entrepreneurial orientation and regional expansion. Entrepreneurship and Regional Development 29(1-2):4-26

Bryman, A. (2012). Social research methods (4th ed.). New York: Oxford University Press.

Burgelman RA (1983) Corporate entrepreneurship and strategic management: insights from a process study. Manag Sci 29(12):1349-1364

Burt RS (2001) Structural holes versus network closure as social capital. In: Lin N, Cook K, Burt RS (eds) Social capital: theory and research. Aldine de Gruyter, New York, pp 31-56

Cavusgil ST, Zou SM (1994) Marketing strategy-performance relationship: an investigation of the empirical link in export market ventures. J Mark 58(1):1-21

Commission, E (2003) Commission Recommendation of 6 May 2003: Concerning the definition of micro, small and medium-sized enterprises. Off J Eur Union L124:36-41

Contractor FJ, Kundu S (2004) The role of export-driven entrepreneurship in economic development: a comparison of software exports from India, China, and Taiwan. Technol Forecast Soc Chang 71(8):799822

Covin JG, Miles MP (1999) Corporate entrepreneurship and the pursuit of competitive advantage. Entrep Theory Pract 23(3):47-63

Covin JG, Slevin DP (1989) Strategic management of small firms in hostile and benign environments. Strateg Manag J 10(1):75-87

Covin JG, Slevin DP (1991) A conceptual model of entrepreneurship as firm behavior. Entrep Theory Pract 16(1):7-25

Dess GG, Robinson RB (1984) Measuring organizational performance in the absence of objective measuresthe case of the privately-held firm and conglomerate business unit. Strateg Manag J 5(3):265-273

Dess GG, Pinkham BC, Yang H (2011) Entrepreneurial orientation: assessing the construct's validity and addressing some of its implications for research in the areas of family business and organizational learning. Entrep Theory Pract 35(5):1077-1090

Diamantopoulos A (2011) Incorporating formative measures into covariance-based structural equation models. MIS Q 35(2):335-358

Dimitratos P, Lioukas S, Carter S (2004) The relationship between entrepreneurship and international performance: the importance of domestic environment. Int Bus Rev 13(1):19-41

Dunning JH (1988) The eclectic paradigm of international production: a restatement and some possible extensions. J Int Bus Stud 19(1):1-31. https://doi.org/10.1057/palgrave.jibs.8490372

Fornell, C., \& Larcker, D. F. (1981). Structural equation models with unobservable variables and measurement error: algebra and statistics. J Mark Res, 18(3), 382-388.

Garcia R, Calantone R (2002) A critical look at technological innovation typology and innovativeness terminology: a literature review. J Prod Innov Manag 19(2):110-132 
Gartner WB, Baker T (2010) A plausible history and exploration of Stevenson's definition of entrepreneurship. Paper presented at the Frontiers of entrepreneurship research

Glavas C, Mathews S, Bianchi C (2017) International opportunity recognition as a critical component for leveraging Internet capabilities and international market performance. J Int Entrep 15(1):1-35

Hair JF, Hult GTM, Ringle C, Sarstedt M (2014) A primer on partial least squares structural equation modeling (PLS-SEM). Sage, Thousand Oaks

Hansen JD, Deitz GD, Tokman M, Marino LD, Weaver KM (2011) Cross-national invariance of the entrepreneurial orientation scale. J Bus Ventur 26(1):61-78

Henseler J, Chin WW (2010) A comparison of approaches for the analysis of interaction effects between latent variables using partial least squares path modeling. Struct Equ Model Multidiscip J 17(1):82-109

Hernandez-Perlines F (2018) Moderating effect of absorptive capacity on the entrepreneurial orientation of international performance of family businesses. Journal of Family Business Management 8(58):74

Hornsby JS, Kuratko DF, Shepherd DA, Bott JP (2009) Managers' corporate entrepreneurial actions: examining perception and position. J Bus Ventur 24(3):236-247

Hosseini M (2016) The internationalization of SMEs: an interactive perspective of firm-level entrepreneurship and network structure. (1776 Doctoral thesis, monograph), Linköping University Electronic Press, Linköping. Retrieved from https://doi.org/10.3384/diss.diva-129230 DiVA database

Hosseininia G, Ramezani A (2016) Factors influencing sustainable entrepreneurship in small and mediumsized enterprises in Iran: a case study of food industry. Sustainability 8(10):1010

Hughes M, Morgan RE (2007) Deconstructing the relationship between entrepreneurial orientation and business performance at the embryonic stage of firm growth. Ind Mark Manag 36(5):651-661

Jantunen A, Puumalainen K, Saarenketo S, Kyläheiko K (2005) Entrepreneurial orientation, dynamic capabilities and international performance. J Int Entrep 3(3):223-243

Jarvis CB, MacKenzie SB, Podsakoff PM (2003) A critical review of construct indicators and measurement model misspecification in marketing and consumer research. J Consum Res 30(2):199-218

Javalgi RG, Todd PR (2011) Entrepreneurial orientation, management commitment, and human capital: the internationalization of SMEs in India. J Bus Res 64(9):1004-1010. https://doi.org/10.1016/j. jbusres.2010.11.024

Jin B, Jung S, Jeong SW (2017) Dimensional effects of Korean SME's entrepreneurial orientation on internationalization and performance: the mediating role of marketing capability. Int Entrep Manag J 14(1):195-215

Johanson J, Vahlne JE (1977) The internationalization process of the firm: a model of knowledge development and increasing foreign market commitments. J Int Bus Stud 8(1):23-32

Klammer A, Gueldenberg S, Kraus S, O’Dwyer M (2016) To change or not to change-antecedents and outcomes of strategic renewal in SMEs. Int Entrep Manag J

Knight GA (1997) Cross-cultural reliability and validity of a scale to measure firm entrepreneurial orientation. J Bus Ventur 12(3):213-225

Knight GA (2000) Entrepreneurship and marketing strategy: the SME under globalization. J Int Mark 8(2):1232

Knight GA, Cavusgil ST (2004) Innovation, organizational capabilities, and the born-global firm. J Int Bus Stud 35(2):124-141

Kuhn B, Sassmannshausen S, Zolin R (2010) "Entrepreneurial management" as a strategic choice in firm behavior: linking it with performance

Lan Q, Wu S (2010) An empirical study of entrepreneurial orientation and degree of internationalization of small and medium sized Chinese manufacturing enterprises. Journal of Chinese Entrepreneurship 2(1): 53-75. https://doi.org/10.1108/17561391011019023

Liu Y, Li Y, Xue JQ (2011) Ownership, strategic orientation and internationalization in emerging markets. J World Bus 46(3):381-393

Lumpkin GT, Dess GG (1996) Clarifying the entrepreneurial orientation construct and linking it to performance. Acad Manag Rev 21(1):135-172

Lumpkin GT, Dess GG (2001) Linking two dimensions of entrepreneurial orientation to firm performance: the moderating role of environment and industry life cycle. J Bus Ventur 16(5):429-451

Lyon DW, Lumpkin GT, Dess GD (2000) Enhancing entrepreneurial orientation research: operationalizing and measuring a key strategic decision making process. J Manag 26(5):1055-1085

MacKenzie SB, Podsakoff PM, Jarvis CB (2005) The problem of measurement model misspecification in behavioral and organizational research and some recommended solutions. J Appl Psychol 90(4):710-730

McDougall PP, Oviatt BM (2000) International entrepreneurship: the intersection of two research paths. Acad Manag J 43(5):902-906 
Memili E, Lumpkin GT, Dess GG (2011) Entrepreneurial orientation: the driving force for corporate entrepreneurship. In: Mazzola P, Kellermanns FW (eds) Handbook of research on strategy process. Edward Elgar Publishing, pp. 624

Menzel HC, Aaltio I, Ulijn JM (2007) On the way to creativity: engineers as intrapreneurs in organizations. Technovation 27(12):732-743

Miller D (1983) The correlates of entrepreneurship in three types of firms. Manag Sci 29(7):770-791

Miller D, Friesen PH (1982) Innovation in conservative and entrepreneurial firms: two models of strategic momentum. Strateg Manag J 3(1):1-25

Morris MH (1998) Entrepreneurial intensity: sustainable advantages for Individuals, organizations and societies. Quorum Books, USA

Mthanti T, Ojah K (2017) Entrepreneurial orientation (EO): measurement and policy implications of entrepreneurship at the macroeconomic level. Res Policy 46(4):724-739

Nahapiet J, Ghoshal S (1998) Social capital, intellectual capital, and the organizational advantage. Acad Manag Rev 23(2):242-266

Pan Y, Li X, Tse D (1999) The impact of order and mode of market entry on profitability and market share. J Int Bus Stud 30(1):81-104

Peng MW (2001) The resource based view and international business. J Manag 27(6):803-829

Peterson RA, Berger DG (1971) Entrepreneurship in organizations: evidence from the popular music industry. Adm Sci Q 16(1):97-106

Petter S, Straub D, Rai A (2007) Specifying formative constructs in information systems research. MIS Q 31(4):623-656

Pinchot G (1985) Intrapreneuring: why you don't have to leave the corporation to become an entrepreneur, 1st edn. Harpercollins, New York

Rauch A, Wiklund J, Lumpkin G, Frese M (2009) Entrepreneurial orientation and business performance: an assessment of past research and suggestions for the future. Entrep Theory Pract 33(3):761-787

Ringle CM, Wende S, Becker JM (2015) SmartPLS 3 (Version 3). Bönningstedt: SmartPLS. Retrieved from http://www.smartpls.com

Ripolles M, Menguzzato M, Sánchez L (2007 Entrepreneurial orientation and international commitment. J Int Entrep 5(3-4):65-83. https://doi.org/10.1007/s10843-007-0016-0

Robertson, C., \& Chetty, S. K. (2000). A contingency-based approach to understanding export performance. Int Bus Rev, 9(2), 211-235

Root F (1994) Entry strategies for international markets, NY: Lexington Books

Saeed S, Yousafzai SY, Engelen A (2014) On cultural and macroeconomic contingencies of the entrepreneurial orientation-performance relationship. Entrep Theory Pract 38(2):255-290

Şahin F, Gürbüz ST (2017) Entrepreneurial orientation and international performance: the moderating role of cultural intelligence. J Manag Organ 1-25

Shane S, Venkataraman S (2000) The promise of entrepreneurship as a field of research. Acad Manag Rev 25(1):217-226

Simsek Z, Veiga JF, Lubatkin MH (2007) The impact of managerial environmental perceptions on corporate entrepreneurship: towards understanding discretionary Slack's pivotal role. J Manag Stud 44(8):13981424

Song G, Min S, Lee S, Seo Y (2017) The effects of network reliance on opportunity recognition: a moderated mediation model of knowledge acquisition and entrepreneurial orientation. Technol Forecast Soc Chang 117:98-107

Stambaugh JE, Martinez J, Lumpkin GT, Kataria N (2017) How well do EO measures and entrepreneurial behavior match? Int Entrep Manag J 13(717):737

Stevenson HH, Jarillo JC (1990) A paradigm of entrepreneurship - entrepreneurial management. Strateg Manag J 11(5):17-27

Sullivan D (1994) Measuring the degree of internationalization of a firm. J Int Bus Stud 25(2):325-342. https://doi.org/10.1057/palgrave.jibs.8490203

Thanos IC, Pavlos D, Sapouna P (2017) The implications of international entrepreneurial orientation, politicization, and hostility upon SME international performance. International Small Business JournalResearching Entrepreneurship 35(4):495-514

UNIDO (2003) Strategy document to enhance the contribution of an efficient and competitive small and medium-sized Enterprise sector to industrial and economic development in the Islamic Republic of Iran. Retrieved from

Venkatraman N, Prescott JE (1990) Environment strategy coalignment: an empirical test of its performance implications. Strateg Manag J 11(1):1-23 
Wales WJ, Gupta VK, Mousa FT (2011) Empirical research on entrepreneurial orientation: an assessment and suggestions for future research. International Small Business Journal 31(4):357-383

Wall TD, Michie J, Patterson M, Wood SJ, Sheehan M, Clegg CW, West M (2004) On the validity of subjective measures of company performance. Pers Psychol 57(1):95-118

Walters PGP, Samiee S (1990) A model for assessing performance in small U.S. exporting firms. Enterp Theory Pract 15(2):33-50

Wang X, Jessup LM, Clay PF (2013) Measurement model in entrepreneurship and small business research: a ten year review. Int Entrep Manag J 11(1):183-212

Wiklund J, Shepherd D (2003) Knowledge-based resources, entrepreneurial orientation, and the performance of small and medium sized businesses. Strateg Manag J 24(13):1307-1314

Wiklund J, Shepherd D (2005) Entrepreneurial orientation and small business performance: a configurational approach. J Bus Ventur 20(1):71-91

Yeoh PL, Jeong I (1995) Contingency relationships between entrepreneurship, export channel structure and environment. A proposed conceptual model of export performance. Eur J Mark 29(8):95-115

Yiu DW, Lau CM, Bruton GD (2007) International venturing by emerging economy firms: the effects of firm capabilities, home country networks, and corporate entrepreneurship. J Int Bus Stud 38(4):519-540

Zahra SA (1991) Predictors and financial outcomes of corporate entrepreneurship: an exploratory study. J Bus Ventur 6(4):259-285

Zahra SA (1993) Environment, corporate entrepreneurship, and financial performance - a taxonomic approach. J Bus Ventur 8(4):319-340

Zahra SA (1996) Goverance, ownership, and corporate entrepreneurship: the moderating impact of industry technological OpportunitiesAuthor. Acad Manag J 39(6):1713-1735

Zahra SA (2005) A theory of international new ventures: a decade of research. J Int Bus Stud 36(1):20-28

Zahra SA, George G (2002) International entrepreneurship: the current status of the field and future research agenda. In: Hitt MA, Ireland RD, Camp SM, Sexton DL (eds) Strategic entrepreneurship: creating a new mindset. Wiley-Blackwell, London, pp 255-288

Zahra SA, Neubaum DO, Huse M (1997) The effect of the environment on export performance among telecommunications new ventures. Entrep Theory Pract 22(1):25-46

Zhang X, Ma X, Wang Y (2012) Entrepreneurial orientation, social capital, and the internationalization of SMEs: evidence from China. Thunderbird International Business Review 54(2):195-210

Zhou LX, Wu WP, Luo XM (2007) Internationalization and the performance of born-global SMEs: the mediating role of social networks. J Int Bus Stud 38(4):673-690

Zhou L, Barnes BR, Lu Y (2009) Entrepreneurial proclivity, capability upgrading and performance advantage of newness among international new ventures. J Int Bus Stud 41(5):882-905 